\title{
IMPLEMENTATION OF ENVIRONMENTAL TECHNOLOGY FOR SUSTAINABLE DEVELOPMENT OF RURAL AREAS IN POLAND
}

\author{
Józef Mosiej \\ Warsaw Agricultural University, Poland
}

\begin{abstract}
In Poland agriculture use $60 \%$ of the land area. There are about 2.5 millions farms and average each of them cover 7 hectare. The farming and weak solutions of sanitary problems contribute substantially to the eutrophication of the Baltic Sea ecosystem, through the river discharge and transport of nutrients.

New knowledge should be transferred to the local authorities and organisations, and in the final end, to the users of land and farmers. It seems important to work for the understanding of how the local environment can improved, which in turn can cause substantial improvement of nutrient losses from land and from the discharge of sewage in small villages.

Diffierent examples of extension ideas of Agenda 21 from Poland and co-operation between Swedish and Polish Universities in implementation ideas of sustainable development which will be presented, shown many possibilities for imitate by others in the Baltic region.
\end{abstract}

\section{KEYWORDS}

Environmental technology, rural area, education, sustainable development, transfer of knowledge.

\section{INTRODUCTION}

The future development of polish rural area is of great importance for Poland, Sweden, and the other country neighbours surrounding the Baltic Sea and, the European Community (EC). In Poland agriculture use $60 \%$ of the land area. There are about 2.5 millions farms and each of them in average cover 7 hectare. The farming technology and weak solutions of sanitary problems contribute substantially to the eutrophication of the Baltic Sea ecosystem, through the river discharge and transport of nutrients. About $26 \%$ of the Polish work force are employed in agriculture. The corresponding for western European countries is $3-5 \%$. The cultivation of more than 2 million hectares of very poor soils in Poland, corresponding to $11 \%$ of the total area, is one of several reasons for extremely low production from a European perspective. In the case of a Polish membership in EC, it seems true that the Polish agriculture has to change its land use remarkably. 
A restructuring of the land use and activation to more productive areas seems truly. This process implies that the landscape must be used in a quite different way than earlier, however, not easy to realise since so many economic and social aspects have to be taken. Ecological problems must also be taken, e.g. the conservation of biological diversity and action in the spirit of Agenda 21.

Degradation of the environment is still considered as very high in Poland despite many investments and initiatives in environmental protection. Hitherto resources have been applied mostly on technical solutions, e.g. wastewater treatment plants, and they have of that reason been very urban-oriented. Improvements of the environmental quality in rural areas have been given lower priority.

A forgotten area for investments is a then new education programme, not only at university level but also for decisions makers, agricultural extension service and for teachers educating at the secondary and post-secondary levels. Sustainable development of rural areas can only be achieved if wide-scale education is included as a mean of long-term investment. The education should focus on the main environmental problems in rural areas in Poland:

- reduction of non-point and point sources of water pollution

- improvement of quantity and quality of water resources

- methods of storage and utilisation of solid agricultural wastes

Desired progress in village sanitation, in accordance to demands, can take place only at the time when farmers incomes will grow higher. For that reason activities aimed at the multifunctional village development enabling farmers income increase are necessary. For realisation of the above-mentioned programme, Poland needs economic sources, time and good examples. Poland tries to transfer good examples from abroad, first of all from Sweden and other Baltic countries, because Baltic is our common border and common Sea. We expect that Swedish experience in ecological and environmental engineering will be useful in Polish conditions (climate, economic and social).

Transfer of knowledge is important and examples of that are some education projects sponsored by EC under PHARE Programme in Poland (Runowski, 1995; Hewelke\&Brandyk, 1995; Hewelke, 1996, Mosiej\&Renman 1997). Several Polish universities participate in The Baltic University Programme (BUP). Every year over 1000 student participated in courses under BUPa

There are also some investment projects sponsored partly by EU and Poland connected with improvement of environmental conditions in rural areas in watershed scale or commune scale where part of projects consists of training and education topics (Roszkowski, 1996).

\section{ENVIRONMENTAL TECHNOLOGY}

Environmental technology or ecotechnology is defined as the use of technological means for ecosystem management based on deep understanding of principles on which natural ecological systems are built and on the transfer of such principles into ecosystem management in a way to minimise the costs of the measures and their harm to the global environment (Mitsch , 1993; Straskraba, 1993). Ecotechnological methods must be extensively applied in East European countries for fast counteraction of environmental problems such as land degradation caused by heavy metal pollution, eutrophication of lakes and rivers and ground water pollution. There are many good reasons for adopting principles of ecotechnology in those countries. First, the knowledge of using ecological services is not unfamiliar among people working with landscape management. Second, the costs for introducing low technology are realistic in the light of the actual economic situation. However, treatment systems based on ecotechnology will be most beneficial in small villages and agglomerations 
in rural areas. Third, the problems with fossil energy utilisation cannot cause further environmental deterioration; hence treatment of pollution should apply the low-energy rules of ecotechnology. The supply of energy will be critical in many areas and introduction of, for instance, energy dependent conventional wastewater treatment plants will be hazardous. There is a considerable interest in ecological purification methods in Poland, a situation caused by insufficient or lack of sewage treatment.

\section{Characteristics of rural areas}

Counteraction of excessive eutrophication of Poland's surface and ground water within drainage basin of the Baltic Sea will require considerations concerning several interconnected issues. Of all the countries around the Baltic Sea, Poland still has quantitatively the biggest impact on the environment of this sea area. There are several reasons for this. Almost the whole of Poland falls within the Baltic drainage basin, and additional half of the population and $40 \%$ of the arable land of the basin as a whole are to be found within the country's borders. Poland as a whole is responsible for $36 \%$ of the nitrogen, $38 \%$ of the phosphorus and over $20 \%$ of the organic matter entering the Baltic. As results of actions undertaken in Poland according to the national environment policy, the significant reduction in the riverine pollution load of point origin has been observed since 1988. The mean contribution of nitrogen and phosphorus loads from non-point sources to the total load is $51 \%$ and $19 \%$ respectively. It is estimated that agricultural sources account for about $30-35 \%$ of the total nitrogen load and about $10 \%$ of the total phosphorus load to the Baltic Sea.

In the total mass of matter discharged to the sea mainly by Vistula, Oder and coastal rivers, the nutrients such as nitrogen and phosphorus are of specific importance. Their origin is related to point and non-point pollution sources. Sewage originating from small towns, rural areas and holiday resorts constitutes about $15 \%$ of total volume of liquid waste produced in Poland. Due to its concentration of nutrients it possess a substantial threat to the environment. The impact of rural domestic sewage has been growing recently in connection with constructing rural water supply systems. The number of rural households equipped with running water facilities has doubled over the past ten years, but sewage management designs were seldom satisfactory. Rural areas will then perform several functions. These are not only food production areas (the attempts were made recently to reduce their role only to this function), but also areas of environment self-cleaning and many biological resources regeneration (Michna, 1995).

Agricultural runoff, in addition to municipal sewage from urban and rural areas and industrial pollution, also contributes significantly to contamination of ground and surface water. In rural areas, village water quality is rather very low in $20 \%$ of household water supply systems, $48 \%$ of common wells, and $66 \%$ of home wells. Thus, nitrate compounds adversely affect the health of $50 \%$ of village populations and bacteria in the water supply. Rural areas are inhabited by about 16 million people, who produce over 1000 million $\mathrm{m}^{3}$ per year, of which only 40 million $\mathrm{m}^{3}$ are treated in sewage treatment plants. It is estimated that only $5 \%$ of farms are equipped with sewage purification system. The rest of farms are using very simple systems of sewage disposal. The rural wastewater are discharged into the soil, ponds and rivers, into ditches and unused wells in a raw, i.e. an untreated condition. Overall, an estimated $65 \%$ of Polish surface waters are considered unfit for municipal or even for industrial use. It is assessed that degradation of surface waters in Poland is so high, that without ecotechnological solutions it is not possible to improve water quality. There is no explicit answer to the question of whether to develop central village sewage systems, i.e. concentrate sewage effluent from houses and farms, or decentralise it, by neutralisation of the effluent at the place of its origin? 
The construction of new wetlands and restoration of natural wetlands is very popular focus in Poland. Wetlands may act as efficient purification systems for water with high nitrogen and phosphorus concentration. In some areas many goals could be achieved by such a strategy.

There are also several systems using natural wetlands under operation. The utilisation of sewage effluents in willow and poplar plantations has a long tradition in Poland. There are reports of some practical examples of the purification of drainage waters from agricultural lands (drainage waters recycling) and non-point pollution control by biological and geochemical barriers.

In Poland several systems based on ecotechnological solutions have been constructed. Nongovernment organisations try to promote ecotechnological solutions for villages and farms. Small systems (constructed wetlands) for one house, one farm or groups of farm are very popular. Most of these systems are composed of vegetation filters with common reed, cattail and willow. There are several systems using natural wetlands. At present about 7000 onsite wastewater systems for individual farms based on ecotechnology concepts are being operated. Over 50 constructed wetlands composed of vegetation filters with common reed or willow (average inflow from 5 to $200 \mathrm{~m}^{3} / \mathrm{d}$ ) and over 40 hydrobotanical systems based on Lemna (duckweed) are installed.

\section{Sustainable development of rural areas through implementation of environmental technology (SUIT)}

The achievement of an environmental sustainable development in Poland through cooperation between universities implies that the results are oriented towards solutions. Unfortunately, such solutions are rather often presented in unavailable forms for the practitioners. Hence to reach large-scale effects the results have to be addressed and implemented in a suitable manner. Then the collaboration between universities and different functions in the society is of decisive importance. The communication between researchers /university teachers and labour groups participating in the implementation of environmental technology is essential. The follow-up procedure of a certain measure is also of great importance, for the universities in the form of feedback of practical application, which in turn can proceed to additional research and improvements.

New knowledge should be transferred to the local authorities and organisations, and in the final end, to the users of land and farmers. It seems important to work for the understanding of how the local environment can improved, which in turn can cause substantial improvement of nutrient losses from land and from the discharge of sewage in small villages. The landscape will then, if not earlier, pass through large changes, which can have many positive effiects on the total environment, i.e. the Baltic Sea and its polish drainage basins. In the frame of the reconstruction process of the Polish agriculture, a technical environmental component has to be included. This should include goals and tools to increase the ability of the farms not only to produce food but also to "produce clean water". Today we unfortunately have the opposite situation, which is not in agreement with the intentions of e.g. Agenda 21. By the help inexpensive low technology, the problems of for instance sewage handling can be solved in rural areas. Much more difficult will be to develop cost-effiective solutions for long-term soil losses of nutrients.

The project SUIT aim as a general goal to consider a part of the above mentioned problem complex. The transfer of knowledge and the co-operation will aim at the creation of a coupled link from university departments to selected groups of regional and local organisations working within the problem area. We intend to influence, through the project, the knowledge in environmental technology not only at universities but also at lower technical education 
units (Fig. 1). The Swedish Institute and a co-operation between the Warsaw University of Technology, the Warsaw Agricultural University and the Royal Institute of Technology support SUIT project. The application of environmental technologies, mainly GIS and ecotechechnology, are carried out in a typical Polish rural commune, Branszczyk and the Ostroleka and Wyszkow Districts. This bilateral co-operation mainly comprises competence transfer, e.g. exchange of experts, advisory services education and training. The most important parts of the programme are exchange of staff between co-operating units, exchange and transfer of knowledge, and development of higher education.

The programme is planed as three-year venture and beginning for long-term co-operation on environmental technologies issues. During the first year of the project, we built organisational and institutional working relationships among community, governmental and educational institutions to enhance the long-term sustainability of the project goals. Several meetings and seminars were and will be held in Poland and Sweden. Representatives from Branszczyk Commune and Ostroleka District have visited Sollentuna and Äkersberga

Municipalities and discussed several environmental problems. Polish partners interested in institutional aspects of environmental investments in Sweden. During the second year of the project, short intensive course for local decision-makers from communes and districts was organised. Local "Agenda 21" was the main subject of the training. As a final results of the SUIT project will be programme of eco-development for Brańszczyk Commune. 


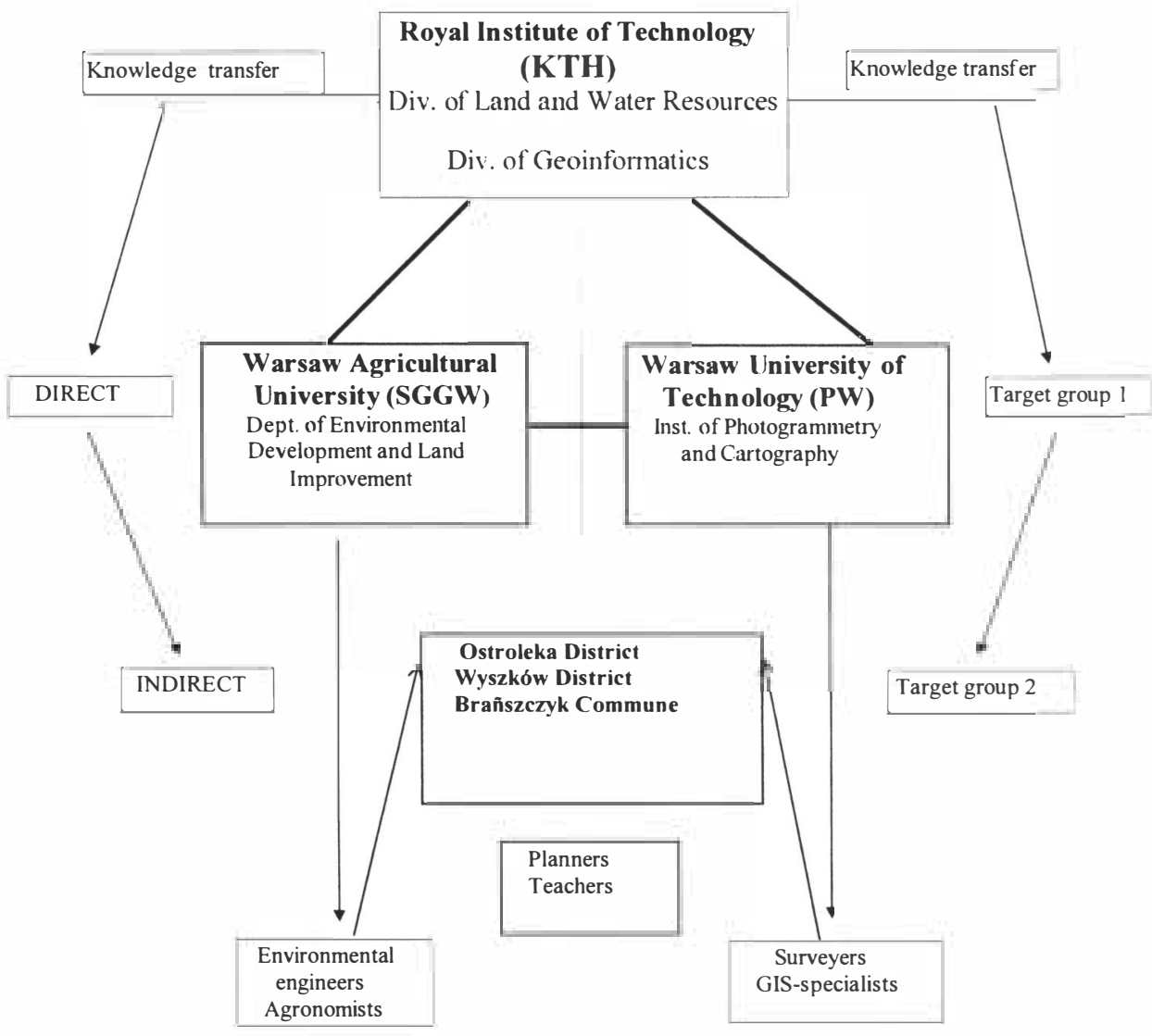

Figure 1.

The model of the co-operation between universities, local and govemmental administrations in the SUIT project 


\section{List of references}

Hewelke P.. Brandyk T. (1995). Postgraduate Education in Protection and Sustainable Development of Rural Areas" (in Polish). Edukacja Doroslych, 4/5, 198-201.

Hewelke P. (1996). Postgraduate Studies in Protection and Sustainable Development of Rural Areas" (in Polish). Edukacja Doroslych, 3, 121-125.

Michna W.(ed.). (1995). Non-point pollution from agricultural sources and approaches to reduce it in Poland. Report of project WHO-UNEP no FP 5201.

Mitsch W.J. (1993). Ecological engineering. Environ. Sci. Technol., Vol. 27, 3, 438-445.

Mosiej J.. Renman G. (1997). Rural Environmental Engineering - the need of education in Poland. In:"Implementation of environmental education in the community". Proceedings of 5th conference CEEE`97, Harnosand, 251-261.

Roszkowski H., (1996). Implementation of environmental friendly agriculture in Narew Catchment. Proposal of project PHAREa FAPA, (in Polish). AGROCONSULT, Warszawa. Runowski H., (1995). Priority Training for Extension Service. Final Report from implementation of project PHARE No 9105-03-07 (in Polish). FAPA - AGROEXPERT.

Straskraba M., (1993). Ecotechnology as a new means for environmental management. Ecological Engineering: 2 (4), 311-331. DOl: https:/doi.org/10.1016/0925-8574(93)90001-V 